\title{
Long noncoding RNAs in digestive system cancers: Functional roles, molecular mechanisms, and clinical implications (Review)
}

\author{
MIN FU ${ }^{1,2}$, CHEN ZOU $^{1}$, LEI PAN ${ }^{1}$, WEI LIANG ${ }^{2}$, HUI QIAN $^{2}$, WENRONG XU $^{2}$, \\ PENGCHENG JIANG $^{1}$ and XU ZHANG ${ }^{2}$ \\ ${ }^{1}$ Department of General Surgery, The Affiliated People's Hospital of Jiangsu University, Zhenjiang, Jiangsu 212002; \\ ${ }^{2}$ Jiangsu Key Laboratory of Medical Science and Laboratory Medicine, School of Medicine, \\ Jiangsu University, Zhenjiang, Jiangsu 212013, P.R. China
}

Received February 26, 2016; Accepted July 4, 2016

DOI: $10.3892 /$ or.2016.4929

\begin{abstract}
Long noncoding RNAs (lncRNAs) are emerging as new players in various diseases including cancer. LncRNAs have been shown to play multifaceted roles in the development, progression, and metastasis of cancer. In this review, we highlight the lncRNAs that are critically involved in the pathogenesis of digestive system cancers (DSCs). We summarize the roles of the lncRNAs in DSCs and the underlying mechanisms responsible for their functions. The DSC-associated lncRNAs interact with a wide spectrum of molecules to regulate gene expression at transcriptional, post-transcriptional, and translational levels. We also provide new insights into the clinical significance of these lncRNAs, which are found to be closely associated with the aggressiveness of DSCs and could predict the prognosis of DSC patients. Moreover, lncRNAs have been suggested as promising therapeutic targets in DSCs. Therefore, better understanding of the functional roles of IncRNAs will provide new biomarkers for DSC diagnosis, prognosis, and therapy.
\end{abstract}

\section{Contents}

1. Introduction

2. The functional roles of DSC-related lncRNAs

3. The clinical significance of DSC-related lncRNAs

4. Conclusion

Correspondence to: $\mathrm{Dr} \mathrm{Xu}$ Zhang, Jiangsu Key Laboratory of Medical Science and Laboratory Medicine, School of Medicine, Jiangsu University, 301 Xuefu Road, Zhenjiang, Jiangsu 212013, P.R. China

E-mail: xuzhang@ujs.edu.cn

Dr Pengcheng Jiang, Department of General Surgery, The Affiliated People's Hospital of Jiangsu University, 8 Dianli Road, Zhenjiang, Jiangsu 212002, P.R. China

E-mail: pc_jiang@126.com

Key words: long noncoding RNA, digestive system cancer, biomarker, target, therapy

\section{Introduction}

Digestive system cancers (DSCs) are common cancers and the leading causes of cancer-related deaths worldwide (1). According to the classification by the World Health Organization in 2010 (2), DSCs consist of alimentary tract cancers of the esophagus, stomach, colorectum, and digestive gland cancers of the liver, gallbladder, bile duct, and pancreas. Although great advances in surgical techniques and chemotherapy have been achieved, the prognosis of DSCs is still poor since they are mostly diagnosed at advanced stage, which may be accompanied by malignant proliferation, extensive invasion, and distant metastasis $(3,4)$. Genetic and epigenetic alterations have been suggested to participate in the development and progression of DSCs (5-7). The elucidation of the molecular regulatory network in DSCs will provide novel biomarkers for early diagnosis and more effective therapy.

Over the past decade, noncoding RNAs are emerging as new players in various diseases. Long noncoding RNAs (lncRNAs) are defined as transcripts of greater than 200 nucleotides that lack protein-coding capability (8). LncRNAs regulate gene expression at various levels, including chromatin modification (9), transcription (10), and post-transcription $(11,12)$. Increasing evidence suggests that lncRNAs play important roles in cancer (13). LncRNAs are critically involved in tumorigenesis, tumor growth, and tumor metastasis (14). In this review, we present an updated view of the roles of IncRNAs in DSCs with an emphasis on the underlying mechanisms. We also provide new insights into the prospective of lncRNAs as potential diagnostic biomarkers and therapeutic targets for DSCs.

\section{The functional roles of DSC-related IncRNAs}

To identify the lncRNAs most closely related to DSCs, a systematic literature search was conducted to find all the lncRNAs which have been reported in esophageal, stomach, colorectal, liver, gallbladder, bile duct, and pancreatic cancers. LncRNAs that are involved in at least three types of DSCs were included for further review. A total of ten IncRNAs were included, which are H19, Hox transcript antisense intergenic RNA (HOTAIR), metastasis-associated lung 
Table I. The expression of IncRNAs in DSCs.

\begin{tabular}{|c|c|c|c|c|c|}
\hline LncRNA & Size & $\begin{array}{l}\text { Gene } \\
\text { location }\end{array}$ & $\begin{array}{l}\text { Expression } \\
\text { change }\end{array}$ & DSC type & Refs. \\
\hline H19 & $2.3 \mathrm{~kb}$ & $11 \mathrm{p} 15.5$ & Upregulated & Esophagus, stomach, colorectum, pancreas & $(21,23,25,32)$ \\
\hline HOTAIR & $2.2 \mathrm{~kb}$ & $12 q 13.13$ & Upregulated & $\begin{array}{l}\text { Esophagus, stomach, colorectum, liver, } \\
\text { gallbladder, pancreas }\end{array}$ & $(36,38-40,137,148)$ \\
\hline MALAT1 & $8.1 \mathrm{~kb}$ & $11 \mathrm{q} 13.1$ & Upregulated & $\begin{array}{l}\text { Esophagus, stomach, colorectum, liver, } \\
\text { gallbladder, pancreas }\end{array}$ & $(52,53,60,149,150)$ \\
\hline HULC & $\sim 500 \mathrm{nt}$ & $6 \mathrm{p} 24.3$ & Upregulated & Stomach, liver, pancreas & $(71,72,75)$ \\
\hline MEG3 & $1.6 \mathrm{~kb}$ & $14 \mathrm{q} 32.2$ & Downregulated & Stomach, colorectum, liver, pancreas & $(80,82,86,89)$ \\
\hline GAS5 & $630 \mathrm{nt}$ & $1 \mathrm{q} 25$ & Downregulated & Stomach, colorectum, liver, pancreas & $(92-94,96)$ \\
\hline ANRIL & $3.8 \mathrm{~kb}$ & $9 \mathrm{p} 21.3$ & Upregulated & Esophagus, stomach, colorectum, liver & $(103,104,106,107)$ \\
\hline PVT1 & $>300 \mathrm{~kb}$ & $8 \mathrm{q} 24$ & Upregulated & Stomach, colorectum, liver, pancreas & $(109-112)$ \\
\hline CCAT1 & $2628 \mathrm{nt}$ & $8 \mathrm{q} 24.21$ & Upregulated & Stomach, colorectum, liver, gallbladder & $(12,120,121,151)$ \\
\hline LncRNA-ATB & $162 \mathrm{~kb}$ & $14 q-$ & Upregulated & Stomach, colorectum, liver & $(122-124)$ \\
\hline
\end{tabular}

LncRNAs, long noncoding RNAs; DSCs, digestive system cancers; HOTAIR, Hox transcript antisense intergenic RNA; MALAT1, metastasis-associated lung adenocarcinoma transcript 1; HULC, highly upregulated in liver cancer; MEG3, maternally expressed gene 3; GAS5, growth arrest-specific transcript 5; ANRIL, antisense noncoding RNA in the INK4 locus; PVT1, plasmacytoma variant translocation 1; CCAT1, colon cancer associated transcript 1 .

adenocarcinoma transcript 1 (MALAT1), highly upregulated in liver cancer (HULC), maternally expressed gene 3 (MEG3), growth arrest-specific transcript 5 (GAS5), antisense noncoding RNA in the INK4 locus (ANRIL), plasmacytoma variant translocation 1 (PVT1), colon cancer associated transcript 1 (CCAT1), and lncRNA-ATB. The characteristics of these DSCs-related lncRNAs are shown in Table I. The functional roles and clinical correlations of these lncRNAs in DSCs are presented in Table II. The upstream signaling pathways and downstream targets for DSC-related IncRNAs are reviewed in Fig. 1.

H19. The H19 gene, located at chromosome 11p15.5, belongs to a highly conserved cluster of imprinted genes which involve the insulin-like growth factor 2 gene (15). H19 is expressed exclusively from the maternal allele and encodes a $2.3 \mathrm{~kb}$ IncRNA (16). During the past decade, extensive research has been carried out on H19 in various cancers. Initially, H19 was found to be tumor-suppressive because of its abilities to repress tumorigenicity (17). However, increasing evidence suggests that H19 is upregulated in most cancers and has oncogenic properties (18-20). In particular, the upregulated levels of $\mathrm{H} 19$ have been confirmed in most DSCs, except the less studied gallbladder cancer (21-25). The role of H19 in liver cancer is still controversial, with some studies showing beneficial $(26,27)$ and the others showing detrimental $(28,29)$ effects to cancer progression.

Yang et al demonstrated that H19 expression is markedly increased in gastric cancer cell lines and tumor tissues. The ectopic expression of $\mathrm{H} 19$ increases cell proliferation, whereas H19 knockdown induces cell apoptosis in gastric cancer cells. They also suggest that the oncogenic role of H19 is associated with the inactivation of p53 tumor suppressor (30). Zhang et al demonstrated that c-Myc can regulate H19 expression and H19 level is positively correlated with that of c-Myc in gastric cancer tissues (31). H19 is also highly expressed in colorectal cancer cell lines and tumor tissues, promoting tumor growth and metastasis both in vitro and in vivo (23). Notably, miR-675 is co-expressed with $\mathrm{H} 19$ and acts as a pivotal mediator of H19 function in DSCs $(28,32-34)$. In gastric cancer, the tumor suppressor runt-related transcription factor 1 (RUNX1) is validated as a direct target of miR-675 (32). In addition, H19 directly upregulates ISM1 and indirectly suppresses CALN1 via miR-675 in gastric cancer (34). In colorectal cancer, the tumor suppressor retinoblastoma (RB) is directly targeted by miR-675. H19-derived miR-675 promotes colorectal cancer cell growth through suppressing the expression of its target RB (33). In hepatocellular carcinoma, Lv et al showed that the downregulation of $\mathrm{H} 19$ and miR-675 promotes the migration and invasion of hepatocellular carcinoma cells (28). Moreover, miR-675 acts as a positive regulator of H19 (26). In addition to miR-675, other miRNAs have also been confirmed to interact with H19 in DSCs. Zhou et al demonstrated that H19 expression is inversely correlated to miR-141 expression in gastric cancer cells and tissues. miR-141 interacts with H19 in a sequence specific manner and suppresses H19 expression and function (22). In colorectal cancer, H19 acts as a competing endogenous RNA for miR-138 and miR-200a, thereby eliminating the repression of core marker genes for epithelial-to-mesenchymal transition (EMT) including vimentin, ZEB1, and ZEB2 (23). Zhang et al demonstrated that the miR-200 family mediates H19-mediated inhibition of metastasis in hepatocellular carcinoma. H19 activates miR-200 family by promoting histone acetylation, thus resulting in tumor suppression (29).

HOTAIR. The HOTAIR is expressed from the developmental HOXC locus located on chromosome 12q13.13. It was first revealed in breast cancer that IncRNA HOTAIR could promote cancer metastasis through inducing polycomb 
Table II. The functional roles of lncRNAs in DSCs.

\begin{tabular}{|c|c|c|c|c|}
\hline LncRNA & DSC type & Functional roles & Downstream targets & Refs. \\
\hline \multirow[t]{4}{*}{ H19 } & Esophagus & Promotes cell proliferation and invasion & E-cadherin, vimentin, fibronectin & $(21)$ \\
\hline & Stomach & $\begin{array}{l}\text { Promotes cell proliferation, migration, } \\
\text { and invasion }\end{array}$ & ZEB1, miR-675, RUNX1, CALN1 & $(32,34,130)$ \\
\hline & Colorectum & Promotes cell proliferation and invasion & $\begin{array}{l}\mathrm{miR}-138 / \text { vimentin, } \mathrm{miR}-200 \mathrm{a} / \mathrm{ZEB} 1 / 2 \text {, } \\
\mathrm{miR}-675 / \mathrm{Rb}\end{array}$ & $(23,33)$ \\
\hline & Pancreas & Promotes cell migration and invasion & Let7/HMGA-2 & $(25)$ \\
\hline \multirow[t]{6}{*}{ HOTAIR } & Esophagus & $\begin{array}{l}\text { Promotes cell proliferation, migration, } \\
\text { and invasion }\end{array}$ & WIF-1 & $(41,44)$ \\
\hline & Stomach & $\begin{array}{l}\text { Promotes cell survival, proliferation, } \\
\text { migration, and invasion }\end{array}$ & $\begin{array}{l}\mathrm{miR}-331-3 \mathrm{p} / \mathrm{HER} 2, \mathrm{miR}-152 / \mathrm{HLA}-\mathrm{G} \\
\mathrm{PRC} 2 / \mathrm{miR}-34 \mathrm{a} / \mathrm{HGF} / \mathrm{c}-\mathrm{Met} / \text { Snail }\end{array}$ & $(45-47)$ \\
\hline & Colorectum & $\begin{array}{l}\text { Promotes cell proliferation, migration, } \\
\text { invasion, and radiotherapy resistance }\end{array}$ & PRC2 (SUZ12, EZH2, H3K27me3) & $(9,43,137)$ \\
\hline & Liver & $\begin{array}{l}\text { Promotes cell survival, proliferation, } \\
\text { migration, and invasion }\end{array}$ & $\begin{array}{l}\text { SUZ12, ZNF198, RBM38, } \\
\text { E-cadherin, SETD2 }\end{array}$ & $(38,48-50)$ \\
\hline & Gallbladder & Promotes cell proliferation and invasion & miR-130a & (39) \\
\hline & Pancreas & Promotes cell proliferation and invasion & $\mathrm{PRC} 2$ & $(40)$ \\
\hline \multirow[t]{6}{*}{ MALAT1 } & Esophagus & $\begin{array}{l}\text { Promotes cell proliferation, migration, } \\
\text { and invasion }\end{array}$ & $\mathrm{p} 21, \mathrm{p} 27$ & $(52,64,152)$ \\
\hline & Stomach & Promotes cell proliferation & $\mathrm{SF} 2 / \mathrm{ASF}$ & $(53,153)$ \\
\hline & Colorectum & $\begin{array}{l}\text { Promotes cell proliferation, migration, } \\
\text { and invasion }\end{array}$ & AKAP-9, Snail, SFPQ/PTBP2 & $(58-60)$ \\
\hline & Liver & $\begin{array}{l}\text { Promotes cell survival, proliferation, } \\
\text { migration, and invasion }\end{array}$ & - & $(65,66,149)$ \\
\hline & Gallbladder & $\begin{array}{l}\text { Promotes cell proliferation, migration, } \\
\text { and invasion }\end{array}$ & ERK/MAPK & $(56)$ \\
\hline & Pancreas & $\begin{array}{l}\text { Promotes cell stemness, proliferation, } \\
\text { migration, and invasion; angiogenesis; } \\
\text { chemoresistance }\end{array}$ & Sox 2, Bmi-1, c-Myc & $(57,63)$ \\
\hline \multirow[t]{3}{*}{ HULC } & Stomach & $\begin{array}{l}\text { Promotes cell proliferation, migration, } \\
\text { and invasion }\end{array}$ & - & $(71)$ \\
\hline & Liver & $\begin{array}{l}\text { Promotes cell proliferation, migration, } \\
\text { and invasion; angiogenesis }\end{array}$ & $\begin{array}{l}\text { p18, CLOCK, miR-107/E2F1/SPHK1, } \\
\text { miR-9/PPARA/ACSL1/cholesterol }\end{array}$ & $(10,70,74,75)$ \\
\hline & Pancreas & Promotes cell proliferation & - & $(72)$ \\
\hline \multirow[t]{4}{*}{ MEG3 } & Stomach & $\begin{array}{l}\text { Inhibits cell proliferation, migration, } \\
\text { and invasion }\end{array}$ & $\operatorname{miR}-181 / \mathrm{Bcl}-2$ & (79) \\
\hline & Colorectum & Inhibits cell proliferation & p53, cylcin D1 & $(80)$ \\
\hline & Liver & Inhibits cell proliferation & p53 & $(90)$ \\
\hline & Pancreas & Inhibits cell proliferation & c-Met & $(82)$ \\
\hline \multirow[t]{4}{*}{ GAS5 } & Stomach & Inhibits cell proliferation & YBX1, E2F1, p21, CDK6 & $(93,97,98)$ \\
\hline & Colorectum & Inhibits cell proliferation & - & $(92)$ \\
\hline & Liver & $\begin{array}{l}\text { Inhibits cell proliferation, migration, } \\
\text { and invasion }\end{array}$ & miR-21/PDCD4, PTEN, vimentin & $(94,95,140)$ \\
\hline & Pancreas & Inhibits cell proliferation & CDK6 & $(96)$ \\
\hline \multirow[t]{4}{*}{ ANRIL } & Esophagus & Promotes cell proliferation & $\mathrm{p} 15$ & $(103)$ \\
\hline & Stomach & Promotes cell proliferation & miR-99a, miR-449a & $(104)$ \\
\hline & Colorectum & Promotes cell proliferation & - & $(106)$ \\
\hline & Liver & $\begin{array}{l}\text { Promotes cell proliferation, migration, } \\
\text { and invasion }\end{array}$ & $\mathrm{PRC} 2 / \mathrm{KLF} 2$ & $(105,107)$ \\
\hline \multirow[t]{3}{*}{ PVT1 } & Stomach & Promotes cell proliferation & $\begin{array}{l}\text { MDR1, MRP, mTOR, HIF-1 } \alpha, \\
\text { p15 p16 }\end{array}$ & $(109,113,141)$ \\
\hline & Colorectum & Promotes cell proliferation, and invasion & SMAD4 & $(110)$ \\
\hline & Liver & Promotes cell stemness and proliferation & NOP2 & $(111,114)$ \\
\hline
\end{tabular}


Table II. Continued.

\begin{tabular}{|c|c|c|c|c|}
\hline LncRNA & DSC type & Functional roles & Downstream targets & Refs. \\
\hline & Pancreas & Promotes chemoresistance & - & $(112,154)$ \\
\hline \multirow[t]{4}{*}{ CCAT1 } & Stomach & Promotes cell proliferation and migration & - & $(117,151)$ \\
\hline & Colorectum & Promotes cell proliferation and invasion & - & $(115,120)$ \\
\hline & Liver & $\begin{array}{l}\text { Promotes cell proliferation, migration, } \\
\text { and invasion }\end{array}$ & let-7/HMGA2 & $(118,119,121)$ \\
\hline & Gallbladder & Promotes cell proliferation and invasion & miR-218-5p/Bmi-1 & $(12)$ \\
\hline \multirow[t]{3}{*}{ LncRNA-ATB } & Stomach & Promotes cell invasion & $\mathrm{miR}-200 \mathrm{~s} / \mathrm{ZEB}$ & $(123)$ \\
\hline & Colorectum & $\begin{array}{l}\text { Promotes cell proliferation, migration, } \\
\text { and invasion }\end{array}$ & E-cadherin & $(124,125)$ \\
\hline & Liver & Promotes cell invasion & miR-200s, IL-11 & $(122,127)$ \\
\hline
\end{tabular}

LncRNAs, long noncoding RNAs; DSCs, digestive system cancers; HOTAIR, Hox transcript antisense intergenic RNA; MALAT1, metastasis-associated lung adenocarcinoma transcript 1; HULC, highly upregulated in liver cancer; MEG3, maternally expressed gene 3; GAS5, growth arrest-specific transcript 5; ANRIL, antisense noncoding RNA in the INK4 locus; PVT1, plasmacytoma variant translocation 1; CCAT1, colon cancer associated transcript 1; RUNX1, runt-related transcription factor 1.

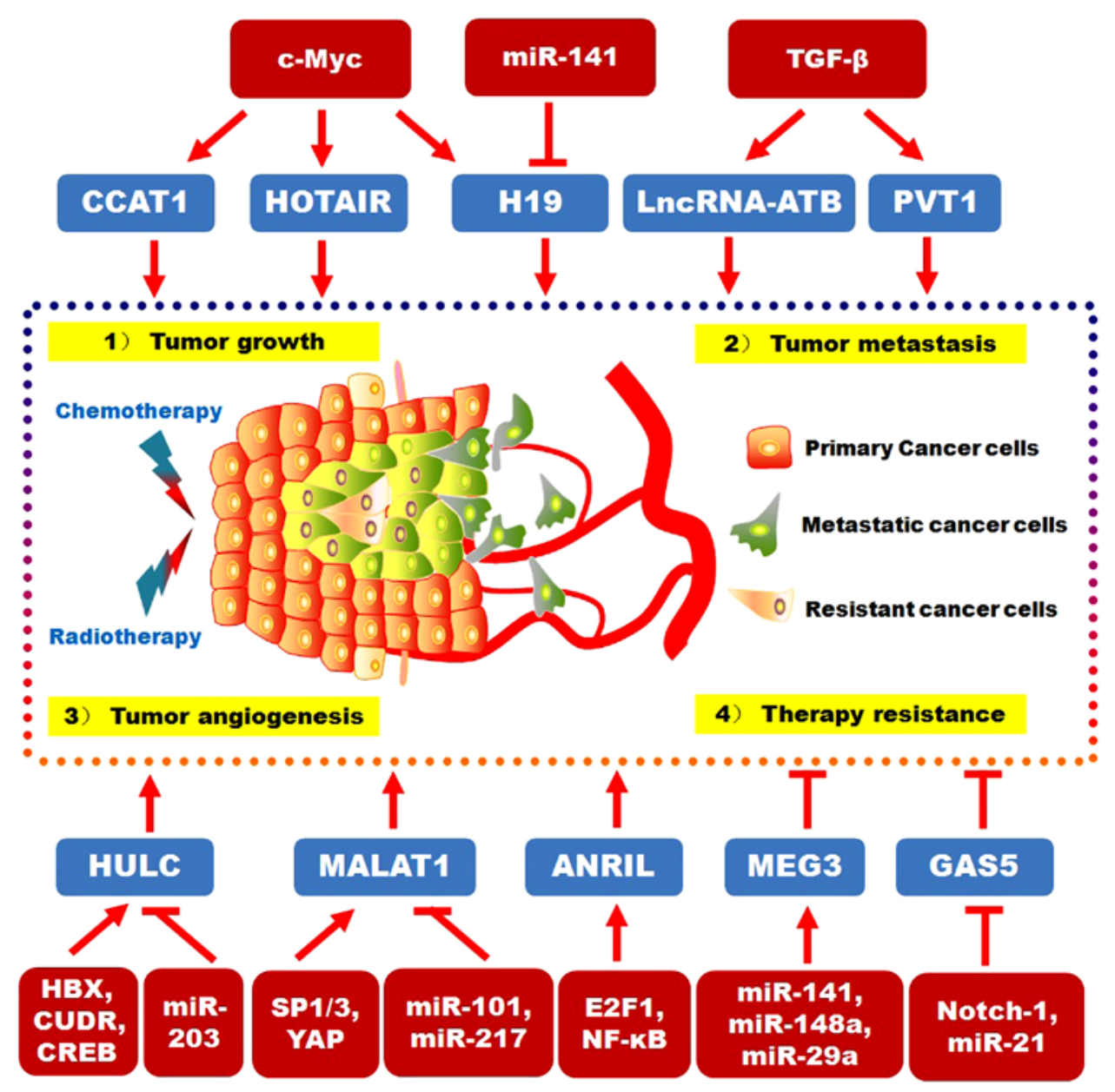

Figure 1. The modulation of long noncoding RNAs (lncRNAs) in digestive system cancers (DSCs). The DSCs-related lncRNAs play either oncogenic or tumor-suppressive roles in tumor growth, metastasis, angiogenesis, and therapy resistance. The deregulated expression of lncRNAs in DSCs is controlled by various factors, including oncoproteins (c-Myc, SP1/3, YAP and Notch1), transcription factors (NF- $\mathrm{B}$, E2F1 and CREB), microRNAs (miR-141, miR-21 and miR-203), and lncRNA (CUDR).

repressive complex 2 (PRC2)-mediated trimethylation of histone H3 lysine-27 (H3K27me3) (35). The enhanced expression of HOTAIR is reported in the cell lines and tumor tissues of most DSCs (9,36-41). In gastric cancer, the increased 
expression of HOTAIR is associated with TNM stage, lymph node metastasis, venous invasion, and poor survival $(37,42)$. HOTAIR knockdown leads to a promotion of radio-sensitivity in colorectal cancer cells (43). In esophageal squamous cell carcinoma, HOTAIR promotes cell migration and invasion by directly downregulating WIF-1 expression and activating the Wnt $\beta$-catenin pathway (44). Song et al suggested that the enhanced expression of HOTAIR in gastric cancer is associated with tumor escape by inhibiting miR-152 and upregulating HLA-G (45). HOTAIR could act as a ceRNA in gastric cancer cells by efficiently binding to miR-331-3p and thereby reactivating HER2 to promote cancer cell growth, migration, and invasion (46). HOTAIR induces the silence of miR-34a via PRC2, promoting EMT in human gastric cancer cells (47). Kogo et al demonstrated that HOTAIR is involved in a genome-wide reprogramming of PRC2 in colorectal cancer. The upregulation of HOTAIR is critical to the metastatic progression (9). Recently, Zhang et al suggested that HOTAIR can promote the proteasomal degradation of SUZ12 and ZNF198 during liver carcinogenesis induced by hepatitis B virus (48). Ye et al demonstrated that HOTAIR induces malignant transformation of liver normal stem cells by downregulating E-cadherin and inducing EMT (49). In liver cancer stem cells, HOTAIR has been shown to promote malignant growth through downregulating SETD2 (50). HOTAIR negatively regulates RNA binding motif protein 38 (RBM38) in hepatocellular carcinoma cells to promote cell motility (38). Ma et al demonstrated that c-Myc induces HOTAIR expression through direct interaction with the promoter region of HOTAIR in gallbladder cancer. In addition, they also suggested that the oncogenic role of HOTAIR functions in part through negatively regulating miRNA-130a (39).

MALAT1. MALAT1, a metastasis-associated lncRNA, was originally discovered to be a marker for metastasis development in early stage lung adenocarcinoma (51). Recently, the upregulated expression of MALAT1 was observed in both cell lines and clinical tissue samples in all types of human DSCs (52-57). Among them, colorectal cancer is most studied for MALAT1 dysregulation (54,58-62). Overexpression of MALAT1 promotes colorectal cancer cell proliferation, migration, and invasion in vitro, and stimulates tumor growth and metastasis in vivo. Reciprocally, the knockdown of MALAT1 inhibits tumor growth and metastasis (60). The higher level of MALAT1 significantly correlates with peritoneal metastasis in gastric cancer patients (53). The knockdown of MALAT1 significantly inhibits the proliferation and metastasis of gallbladder carcinoma cell lines both in vitro and in vivo (56). The inhibition of MALAT-1 could suppress pancreatic cancer cell proliferation, migration, and invasion in vitro (63). A recent study suggests that MALAT-1 overexpression could increase the proportion of cancer stem cells in pancreatic cancer (57).

In esophageal cancer cells, miR-101 and miR-217 conduct an Ago2-dependent post-transcriptional regulation of MALAT1, leading to reduced cell proliferation, migration, and invasion. MALAT1 knockdown significantly represses the proliferation of esophageal squamous cell carcinoma cells, which may be associated with the upregulation of p21 and p27 expression (52). It was suggested that MALAT1 may regulate esophageal squamous cell carcinoma cell proliferation by inactivating the ATM-CHK2 pathway (64). In liver cancer, MALAT1 is upregulated by the oncoprotein Yes-associated protein (YAP) through the interaction with $\mathrm{TCF} / \beta$-catenin on the MALAT1 promoter, which can be inhibited by serine/arginine-rich splicing factor 1 (SRSF1) (65). The knockdown of Sp1 and Sp3 in hepatocellular carcinoma jointly downregulates MALAT1 expression (66). In gallbladder cancer cells, MALAT1 knockdown significantly inhibits the proliferation and metastasis of gallbladder cancer cells in vitro and in vivo through the inactivation of ERK/MAPK signaling pathway (56).

HULC. The lncRNA HULC is regarded as the first lncRNA with highly specific upregulation in hepatocellular carcinoma (67). Compared with normal controls, HULC expression is significantly higher in tumor cells, tumor tissues and plasma of hepatocellular carcinoma patients (68-70). The overexpression of HULC is also reported in gastric cancer and pancreatic cancer and is correlated with advanced lymph node metastasis $(71,72)$. Hepatitis $B$ virus $X$ protein $(\mathrm{HBx})$ contributes to the development of hepatocellular carcinoma. Intriguingly, HULC is involved in HBx-mediated hepatocarcinogenesis. HBx could activate the HULC expression to promote hepatocellular carcinoma cell proliferation through the downregulation of p18 (70). HULC is both a target and a regulator of CREB through its interaction with microRNA-372 in liver cancer cells, providing a fine-tuned auto-regulatory loop (73). HULC is responsible for the perturbations in circadian rhythm through upregulating circadian oscillator CLOCK in hepatoma cells, resulting in the promotion of hepatocarcinogenesis (74). HULC contributes to abnormal lipid metabolism to support the growth of hepatoma cells through the regulation of miR-9-mediated RXRA signaling (10). Recently, Lu et al demonstrated that HULC promotes angiogenesis in liver cancer by upregulating sphingosine kinase 1 (SPHK1). HULC sequesters miR-107 from binding to E2F1 transcription factor and therefore activates E2F1-dependent transcription of SPHK1 (75). Wan et al suggested that HULC could be downregulated by miR-203, leading to the suppression of hepatocellular carcinoma (76). Moreover, HULC could be upregulated by another lncRNA, cancer upregulated drug-resistant gene (CUDR), contributing to the malignant differentiation of liver cancer stem cells (77).

$M E G 3$. MEG3 represents an imprinted gene belonging to the imprinted DLK1-MEG3 locus located at human chromosome $14 \mathrm{q} 32.2$ (78). Accumulating evidence suggests that the expression of MEG3 is decreased in DSCs (79-82). MEG3 is decreased in gastric cancer cell lines and tissues, and its expression is associated with the metastasis of gastric cancer. The overexpression of MEG3 in gastric cancer cells inhibits cell proliferation, migration, invasion, and promotes cell apoptosis (79). MEG3 overexpression could inhibit colorectal cancer cell proliferation both in vitro and in vivo (80). The enforced expression of MEG3 in hepatocellular carcinoma cells significantly decreases both anchorage-dependent and -independent cell growth, and induces apoptosis (81).

The mechanism responsible for the downregulation of MEG3 in cancer remains unclear. The interactions between MEG3 and other molecules in DSCs have been widely studied. Peng et al suggested that lncRNA MEG3 competitively binds 
to the miR-181 family and functions as a ceRNA, upregulating downstream target B-cell lymphoma-2 (Bcl-2), and then suppressing gastric cancer progression (79). Zhou et al recently demonstrated that there is a positive correlation between MEG3 and miR-141 in gastric cancer tissues. They further suggested that miR-141 activates MEG3 by targeting E2F3, which inhibits the proliferation of gastric cancer cells (83). Yan et al demonstrated that the ectopic expression of miR148a activates MEG3 via modulation of DNMT-1 (84). It has been shown that methylation-dependent regulation of MEG3 by miR-29a is involved in hepatocellular carcinoma $(81,85,86)$. Similarly, dendrosomal curcumin upregulates miR-29a and miR-185 and induces DNA hypomethylation, thus promoting the expression of MEG3 in hepatocellular carcinoma (87). The re-expression of MEG3 could lead to the accumulation of p53 protein and its target gene expression, inducing inhibition of cancer cell growth (88). Sun et al also suggested that MEG3 overexpression upregulates the protein level of p53 in gastric cancer cells harboring wild-type p53, indicating that MEG3 may function as a tumor suppressor partially through the activation of p53 in gastric cancer (89). In colorectal and liver cancers, the tumor suppressive role of MEG3 through the activation of p53 is also revealed (80,90). In addition, Modali et al identified MEG3 as a tumor suppressor lncRNA by targeting c-MET to elicit Menin tumor-suppressor activity in pancreatic cancer (82).

GAS5.GAS5, encoded atchromosome 1q25, with about 630 nucleotides in length, was initially discovered during screening for potential tumor suppressor genes (91). Previous studies have shown that GAS5 is downregulated in DSCs, including gastric, colorectal, liver, and pancreatic cancers (92-96). The lower expression of GAS5 is positively correlated with aggressive tumor behavior $(92,93)$. The underlying mechanism for the roles of GAS5 in DSCs is not yet well characterized. In gastric cancer cells, GAS5 binds to the YBX1 protein and regulates its turnover. The downregulation of GAS5 decreases the YBX1 protein level, subsequently inhibiting YBX1-transactivated p21 expression and G1 phase arrest (97). Sun et al also suggested that GAS5 regulates the expression of p21, E2F1, and cyclin D1 in gastric cancer cells through post-transcriptional mechanism (93). In gastric cancer cells and pancreatic cancer cells, GAS5 functions as a tumor suppressor by suppressing the expression of cyclin-dependent kinase (CDK) $6(96,98)$. Chang et al revealed that GAS inhibits hepatoma cell proliferation by the regulation of vimentin (95). GAS5 could also act as ceRNA by binding to miR-21, inhibiting the migration and invasion of hepatocellular carcinoma cells (94).

ANRIL. ANRIL is transcribed as a $3.8 \mathrm{~kb}$ lncRNA from the INK4b-ARF-INK4a gene cluster in the opposite direction $(99,100)$. ANRIL has been identified as a genetic susceptibility locus associated with various diseases including cancer $(101,102)$. Previous studies have shown that ANRIL is upregulated in esophageal squamous cell carcinoma, gastric cancer, colorectal cancer, and hepatocellular carcinoma (103-105). ANRIL is verified as a growth stimulator in esophageal, gastric, and colorectal cancer cells $(103,104,106)$. The knockdown of ANRIL could not only inhibit hepatocellular carcinoma cell proliferation, but also induced cell apoptosis both in vitro and in vivo (107). In esophageal squamous cell carcinoma, the inhibition of ANRIL upregulates the expressions of p15 and TGF $\beta 1$, suggesting a significant role of ANRIL in the development of esophageal squamous cell carcinoma (103). In gastric cancer, ANRIL could indirectly regulate mTOR and CDK6/E2F1 pathway through binding to PRC2 and epigenetically silencing miR-99a/miR-449a, partially accounting for ANRIL-mediated cell growth regulation. In addition, the upregulated E2F1 promotes ANRIL expression and forms a positive feedback loop to promote gastric cancer cell proliferation (104). In hepatocellular carcinoma, ANRIL could epigenetically silence the transcription of Krüppel-like factor 2 (KLF2) by interacting with $\mathrm{PRC} 2$ and recruiting it to the promoter region of KLF2, leading to increased cell proliferation and decreased cell apoptosis (107).

PVT1. PVT1 is documented as an oncogenic lncRNA mapping to chromosome $8 \mathrm{q} 24$ (108). PVT1 locates at a recognized cancer risk locus sharing with the well-known MYC oncogene, which is among the top target loci of copy number alterations in cancer (108). In DSCs, PVT1 expression is upregulated in the tumor tissues of gastric, colorectal, liver, and pancreatic cancers (109-112). The higher level of PVT1 is associated with invasion and advanced TNM stage (113). Univariate and multivariate analyses have revealed that the higher PVT1 expression is associated with poor overall survival and poor recurrence-free survival, which could be an independent prognostic indicator $(110,111)$. Kong et al have recently shown that PVT1 inhibition increases the expression of p15 and p16 and induces G1 phase arrest in gastric cancer cells (113). NOP2 is identified as an RNA-binding protein that binds to PVT1. It is further shown that PVT1 promotes the proliferation and stem cell-like property of hepatocellular carcinoma cells by enhancing the stability of NOP2 (114).

CCAT1. CCAT1, a 2628 nucleotide-lncRNA located on chromosome 8q24.21, was first discovered in colon cancer by Nissan et al in 2012 (115). CCAT1 is strongly expressed in colon cancer tissues but not in normal tissues (115). The upregulation of CCAT1 is evident in pre-malignant conditions and through all disease stages, including advanced metastatic colon cancer (116). Emerging evidence suggests that CCAT1 is also upregulated in other DSCs including gastric cancer, hepatocellular cancer, and gallbladder cancer $(12,117,118)$. The upregulation of CCAT1 is correlated with the growth of primary tumor, lymph node metastasis, and metastatic disease (117), while patients with low expression of CCAT1 demonstrate better overall and relapse-free survival $(119,120)$. $\mathrm{He}$ and colleagues suggest that in colon cancer cells, c-Myc could accelerate CCAT1 transcription by direct binding to its promoter region, and the enhanced expression of CCAT1 promotes cell proliferation and invasion (120). The regulation of CCAT1 by c-Myc is also revealed in gastric cancer and hepatocellular carcinoma $(117,119)$. Moreover, CCAT1 competitively binds to let-7 to antagonize its function and de-represses its targets HMGA2 and c-Myc, thus promoting cell proliferation and migration in hepatocellular carcinoma cells (121). Similarly, CCAT1 promotes the proliferation and invasiveness of gallbladder cancer cells partially through 
'spongeing' miRNA-218-5p and inducing the expression of oncogenic gene Bmil (12).

LncRNA-ATB. LncRNA-AL589182.3 (ENST00000493038) is identified in hepatocellular carcinoma cells as lncRNAactivated by TGF- $\beta$ (lncRNA-ATB) (122). Yuan et al suggested that IncRNA-ATB is a key regulator of TGF- $\beta$ signaling pathway. LncRNA-ATB can be activated by TGF- $\beta$, and subsequently competitively binds to the miR-200 family, leading to the upregulation of ZEB1 and ZEB2 and the induction of EMT. In addition, IncRNA-ATB facilitates hepatocellular carcinoma cell colonization by increasing autocrine induction of IL-11 and activating STAT3 signaling (122). Recent studies have demonstrated the pathological roles of lncRNA-ATB in other DSCs including gastric cancer, colorectal cancer, and pancreatic cancer. LncRNA-ATB is also upregulated in gastric cancer and colorectal cancer and this overexpression is correlated with clinical features and prognosis $(123,124)$. Yue et al demonstrated that lncRNAATB suppresses E-cadherin expression and promotes EMT (125). However, lncRNA-ATB expression is decreased in pancreatic cancer tissues and cell lines. Downregulated expression level of IncRNA-ATB is significantly correlated with lymph node metastases, neural invasion, and clinical stage in pancreatic cancer (126). The roles of lncRNA-ATB in interacting with other miRNAs and mRNA still need to be investigated (127).

\section{The clinical significance of DSC-related IncRNAs}

Diagnostic biomarker. The early diagnosis is critical for the improvement of patient survival. However, traditional tumor biomarkers, such as carcinoembryonic antigen (CEA) and carbohydrate antigen 19-9, present low sensitivity and specificity. Recently, circulating RNA have emerged as non-invasive diagnostic markers. Although the earlier studies concentrated on microRNAs $(128,129)$, the investigations on the diagnostic role of lncRNAs are increasing. In DSCs, there are growing numbers of IncRNAs which have the potential to serve as diagnostic biomarkers. Zhou et al systematically characterized the potential of circulating lncRNAs in plasma as diagnostic markers for gastric cancer. They detected the expression of eight lncRNAs in plasma from gastric cancer patients and healthy subjects. Three lncRNAs (H19, HOTAIR, and MALAT1) were identified with significantly elevated levels in plasma from gastric cancer patients compared to normal controls. Moreover, H19 shows a good stability in the blood and can distinguish early stage gastric cancer, presenting higher sensitivity and specificity than traditional biomarkers (130). Circulating lncRNAs are thought to be unstable due to the high RNase level in plasma, especially in cancer patients carrying more RNase in plasma (131). However, Zhou et al showed that circulating lncRNAs are very stable even when digested directly with RNase A (130), in accordance with another study (132). One possible explanation is that lncRNAs are protected by packaging into microparticles such as exosomes $(133,134)$. Li et al suggested that there is no significant difference in LINC00152 levels between plasma and exosomes, indicating that LINC00152 may be released into the blood by exosomes (135). LINC00152 and HULC are screened out from eight lncRNAs for evaluating the diagnostic value of plasma lncRNAs in hepatocellular carcinoma. Circulating HULC and LINC00152 are significantly upregulated in the plasma of hepatocellular carcinoma patients (69). The combination of HULC, LINC00152, and AFP shows a high prediction value of hepatocellular carcinoma (69). Therefore, the combined analysis of individual lncRNA with traditional biomarkers may improve the sensitivity and specificity of diagnosis and enhance the diagnostic value of lncRNAs.

Prognostic biomarker. The prognostic biomarkers can predict therapeutic effects after certain treatments, thus providing valuable guidance for therapy. There are a number of lncRNAs that have been well characterized as prognostic biomarkers in DSCs (136). The performance of H19 as prognostic marker is still elusive. It is evident that high H19 expression is an independent predictor of the poor overall survival in gastric cancer patients (31). However, in hepatocellular carcinoma patients, low ratio of H19 expression in intratumoral hepatocellular carcinoma tissues to that in peritumoral tissues predicts poor prognosis (29). High ANRIL expression has been suggested to serve as an independent predictor of poor prognosis in both gastric cancer and hepatocellular carcinoma patients $(104,105)$. HOTAIR may serve as an outstanding biomarker for its prognostic value in DSCs including esophageal, gastric, colorectal, liver, and pancreatic cancers $(40,41,47,137,138)$. In particular, the upregulated HOTAIR expression in blood of colorectal cancer patients is associated with unfavorable prognosis, representing an alternative prognostic marker for colorectal cancer (137). For esophageal squamous cell carcinoma, HOTAIR is most commonly identified as negative prognosis marker among these DSC-related lncRNAs $(36,41,44,139)$. Since identified in 2014 (121), IncRNA-ATB has been well characterized for its prognostic value in DSCs. The high level of lncRNAATB is correlated with poor prognosis in liver cancer (121), gastric cancer, and colorectal cancer $(122,123)$. However, the patients with low lncRNA-ATB expression exhibit markedly poor overall survival (125), suggesting a tumor type-dependent role of lncRNA-ATB. The decreased expression of GAS5, a tumor-suppressive lncRNA, could independently predict poor overall survival of gastric, colorectal, and liver cancer patients $(92,93,95,140)$. Frequent recurrence is a major obstacle for long-term survival. Several DSC-related lncRNAs could predict recurrence of hepatocellular carcinoma patients, demonstrating their potential as prognostic biomarkers for recurrence $(55,86,111,119,122,138)$.

Therapeutic target. LncRNAs are considered as potential therapeutic targets in cancer. The specific targeting of lncRNAs could greatly affect the malignant phenotypes such as tumor growth and metastasis. LncRNA-oriented therapies involving small interfering RNAs (siRNAs) target specific oncogenic lncRNAs and show promising anticancer effects. For example, Liu et al showed that HOTAIR knockdown inhibits the metastasis of gastric cancer cells both in vitro and in vivo. They also suggested that therapies targeting HOTAIR lead to improvement for gastric cancer treatment (47). The ectopic overexpression of tumor-suppressive lncRNAs may 
also have anticancer effects. For instance, GAS5 transfected hepatocellular carcinoma cells exhibit decreased migration and invasion, indicating the potential of GAS5 as a target for hepatocellular carcinoma therapy (94). Another strategy is to interfere with the functional molecules that interact with DSC-related lncRNAs. PRKA A-kinase anchor protein 9 (AKAP-9) is a target of MALAT1 and highly expressed in human primary colorectal cancer tissues with lymph node metastasis. The knockdown of AKAP-9 inhibits MALAT1-mediated in vivo cell proliferation, migration and invasion, which may become a potential therapy for colorectal cancer (60). The development of multidrug resistance (MDR) is a major reason for therapy failure in cancer, leading to recurrence and metastasis. Recent studies revealed that lncRNAs play an important role in MDR for DSCs. For example, the cisplatin-resistant gastric cancer cells transfected with PVT-1 siRNA and treated with cisplatin exhibit significant higher apoptosis and lower survival rate, suggesting that PVT1 may be an effective target for reversing MDR in gastric cancer therapy (141). Similarly, the IncRNAs MRUL and HOTTIP also represent potential targets to reverse the MDR phenotype in DSC $(142,143)$. In addition, the intra-arterially administered DTA-H19 plasmid (also known as BC-819), carrying the diphtheria toxin A-chain gene under the regulation of the H19 promoter sequence, significantly repress the tumor growth of the rat liver metastases from colon cancer (144). The combined treatment of BC-819 and gemcitabine show desirable antitumor activity in animal models with pancreatic carcinoma (145), suggesting a promising therapeutic value to be further evaluated in clinical trial (146). Despite the emerging studies, the research is still in its infancy for the therapeutic role of lncRNAs. Further studies and large clinical trials need to be conducted to investigate the clinical therapeutic interventions of lncRNAs in DSCs.

\section{Conclusion}

Accumulating evidence suggests that lncRNAs function as oncogenes or tumor suppressors in DSCs. A group of lncRNAs including H19, HOTAIR, MALAT1, HULC, MEG3, GAS5, ANRIL, PVT1, CCAT1, and lncRNA-ATB generally share consistent functions in different types of DSCs. The dysregulated expression of these IncRNAs affects tumor development, progression, and metastasis in DSCs. Moreover, lncRNAs exhibit clinical significance in serving as potential diagnostic and prognostic biomarkers and therapeutic targets in DSCs.

The convenient detection of circulating lncRNAs in blood and body fluids such as gastric juice can reflect the malignancy of cancer, which is valuable in distinguishing DSC patients from benign diseases and healthy individuals with the advantages of non-invasiveness and cost-effectiveness. However, the use of lncRNAs for diagnosis still has several issues of concern. First, the concentration of measured circulating lncRNAs may not represent the actual amount in the diagnosed patients. The stability of circulating lncRNAs, which may result in unreliable diagnostic accuracy, needs further validation. Second, as one certain lncRNA can be involved in various types of DSCs, the diagnostic specificity and sensitivity need to be explored and improved. One feasible solution is combined diagnosis. The combined diagnosis of different lncRNAs, or with other biomarkers such as traditional biomarkers and circulating miRNAs, may increase the diagnostic accuracy. Third, the cohort size presented in current studies is generally too small for the validation steps. Therefore, prospective studies with large cohort size should investigate the practicability of using circulating lncRNAs, as well as combination with miRNAs or other molecules, as diagnostic biomarkers for DSCs.

The study of lncRNAs as therapeutic targets is still in its early stage and has not reached the clinical practice for DSCs. Several challenges are hindering the development of IncRNA-oriented therapeutics. First, the large size of lncRNAs frequently generates secondary structures, which makes it difficult for the design of siRNAs. Besides, the obstacles for RNA therapies such as side effects and lack of delivery methods and appropriate vectors also impede the clinical use of lncRNAs (147). Moreover, most lncRNAs are not conserved evolutionarily, which makes animal models unavailable prior to clinical applications. Ultimately, the role of DSC-related IncRNAs in interacting with other molecules, including DNA, RNA, and proteins remains not completely understood. Identifying the pivotal role of lncRNAs in DSCs and elucidating their mechanisms will help to block malignant signaling and to specifically eliminate DSC cells.

Therefore, great efforts should be continuously made to further elucidate the IncRNA-based regulatory network in DSCs. Large scaled clinical trials are required to select candidate lncRNAs as novel biomarkers with sufficient sensitivity and specificity, as well as to evaluate the effect of combined diagnosis along with other biomarkers. Further studies focusing on improving the therapeutic effect while minimizing the side effect of lncRNA-based therapy should also be conducted. Thus, better understanding of the functional roles of lncRNAs in DSCs would provide new strategies for the early diagnosis and targeted therapy of DSCs.

\section{Acknowledgements}

This study was funded by the National Natural Science Foundation of China (81201660), the Natural Science Foundation of Jiangsu Province (BK20141303), the Key Research and Development Project of Zhenjiang (SH2015034), the Jiangsu Key Laboratory of Medical Science and Laboratory Medicine Project (JSKLM-2014-006), and the Key R\&D Special Fund of Jiangsu Province (BE2015666).

\section{References}

1. Torre LA, Bray F, Siegel RL, Ferlay J, Lortet-Tieulent J and Jemal A: Global cancer statistics, 2012. CA Cancer J Clin 65: 87-108, 2015.

2. Bosman FT, Carneiro F, Hruban RH and Theise ND: WHO Classification of Tumours of the Digestive System. 4th edition. IARC Press, Geneva, 2010.

3. Thiel A and Ristimäki A: Targeted therapy in gastric cancer. APMIS 123: 365-372, 2015

4. Carr BI and Guerra V: HCC and its microenvironment. Hepatogastroenterology 60: 1433-1437, 2013.

5. Waraya M, Yamashita K, Ema A, Katada N, Kikuchi S and Watanabe M: Exclusive association of $p 53$ mutation with superhigh methylation of tumor suppressor genes in the $p 53$ pathway in a unique gastric cancer phenotype. PLoS One 10: e0139902, 2015. 
6. Sakai E, Fukuyo M, Ohata K, Matsusaka K, Doi N, Mano Y, Takane K, Abe H, Yagi K, Matsuhashi N, et al: Genetic and epigenetic aberrations occurring in colorectal tumors associated with serrated pathway. Int J Cancer 138: 1634-1644, 2016.

7. Anwar SL, Krech T, Hasemeier B, Schipper E, Schweitzer N, Vogel A, Kreipe H and Lehmann U: Loss of DNA methylation at imprinted loci is a frequent event in hepatocellular carcinoma and identifies patients with shortened survival. Clin Epigenetics 7: 110, 2015.

8. Ponting CP, Oliver PL and Reik W: Evolution and functions of long noncoding RNAs. Cell 136: 629-641, 2009.

9. Kogo R, Shimamura T, Mimori K, Kawahara K, Imoto S, Sudo T, Tanaka F, Shibata K, Suzuki A, Komune S, et al: Long noncoding RNA HOTAIR regulates polycomb-dependent chromatin modification and is associated with poor prognosis in colorectal cancers. Cancer Res 71: 6320-6326, 2011.

10. Cui M, Xiao Z, Wang Y, Zheng M, Song T, Cai X, Sun B, Ye L and Zhang X: Long noncoding RNA HULC modulates abnormal lipid metabolism in hepatoma cells through an miR-9-mediated RXRA signaling pathway. Cancer Res 75: 846-857, 2015.

11. Shi Y, Liu Y, Wang J, Jie D, Yun T, Li W, Yan L, Wang K and Feng J: Downregulated long noncoding RNA BANCR promotes the proliferation of colorectal cancer cells via downregualtion of p21 expression. PLoS One 10: e0122679, 2015

12. Ma MZ, Chu BF, Zhang Y, Weng MZ, Qin YY, Gong W and Quan ZW: Long non-coding RNA CCAT1 promotes gallbladder cancer development via negative modulation of miRNA-218-5p. Cell Death Dis 6: e1583, 2015

13. Meseure D, Drak Alsibai K, Nicolas A, Bieche I and Morillon A Long noncoding RNAs as new architects in cancer epigenetics, prognostic biomarkers, and potential therapeutic targets. Biomed Res Int 2015: 320214, 2015

14. Lin Z, Hu Y, Lai S, Xue M, Lin J, Qian Y, Zhuo W, Chen S, Si J and Wang L: Long noncoding RNA: Its partners and their roles in cancer. Neoplasma 62: 846-854, 2015.

15. Ayesh S, Matouk I, Schneider T, Ohana P, Laster M, Al-Sharef W, De-Groot N and Hochberg A: Possible physiological role of $\mathrm{H} 19$ RNA. Mol Carcinog 35: 63-74, 2002.

16. Gabory A, Ripoche MA, Yoshimizu T and Dandolo L: The H19 gene: Regulation and function of a non-coding RNA. Cytogenet Genome Res 113: 188-193, 2006

17. Hao Y, Crenshaw T, Moulton T, Newcomb E and Tycko B: Tumour-suppressor activity of H19 RNA. Nature 365: 764-767, 1993.

18. Luo M, Li Z, Wang W, Zeng Y, Liu Z and Qiu J: Upregulated H19 contributes to bladder cancer cell proliferation by regulating ID2 expression. FEBS J 280: 1709-1716, 2013.

19. Shi Y, Wang Y, Luan W, Wang P, Tao T, Zhang J, Qian J, Liu N and You Y: Long non-coding RNA H19 promotes glioma cell invasion by deriving miR-675. PLoS One 9: e86295, 2014.

20. Vennin C, Spruyt N, Dahmani F, Julien S, Bertucci F, Finetti P, Chassat T, Bourette RP, Le Bourhis X and Adriaenssens E: H19 non coding RNA-derived miR-675 enhances tumorigenesis and metastasis of breast cancer cells by downregulating c-Cbl and Cbl-b. Oncotarget 6: 29209-29223, 2015.

21. Huang C, Cao L, Qiu L, Dai X, Ma L, Zhou Y, Li H, Gao M, $\mathrm{Li}$ W, Zhang Q, et al: Upregulation of $\mathrm{H} 19$ promotes invasion and induces epithelial-to-mesenchymal transition in esophageal cancer. Oncol Lett 10: 291-296, 2015.

22. Zhou X, Ye F, Yin C, Zhuang Y, Yue G and Zhang G: The Interaction between miR-141 and lncRNA-H19 in regulating cell proliferation and migration in gastric cancer. Cell Physio Biochem 36: 1440-1452, 2015.

23. Liang WC, Fu WM, Wong CW, Wang Y, Wang WM, Hu GX, Zhang L, Xiao LJ, Wan DC, Zhang JF, et al: The lncRNA H19 promotes epithelial to mesenchymal transition by functioning as miRNA sponges in colorectal cancer. Oncotarget 6: 22513-22525, 2015.

24. Yang Z, Lu Y, Xu Q, Tang B, Park CK and Chen X: HULC and H19 played different roles in overall and disease-free survival from hepatocellular carcinoma after curative hepatectomy: A preliminary analysis from gene expression omnibus. Dis Markers 2015: 191029, 2015.

25. Ma C, Nong K, Zhu H, Wang W, Huang X, Yuan Z and Ai K H19 promotes pancreatic cancer metastasis by derepressing let-7's suppression on its target HMGA2-mediated EMT. Tumour Biol 35: 9163-9169, 2014

26. Li H, Li J, Jia S, Wu M, An J, Zheng Q, Zhang W and Lu D miR675 upregulates long noncoding RNA H19 through activating EGR1 in human liver cancer. Oncotarget 6: 31958-31984, 2015 .
27. Lv J, Yu YQ, Li SQ, Luo L and Wang Q: Aflatoxin B1 promotes cell growth and invasion in hepatocellular carcinoma HepG2 cells through H19 and E2F1. Asian Pac J Cancer Prev 15 2565-2570, 2014

28. Lv J, Ma L, Chen XL, Huang XH and Wang Q: Downregulation of LncRNAH19 and MiR-675 promotes migration and invasion of human hepatocellular carcinoma cells through AKT/GSK-3ß/Cdc25A signaling pathway. J Huazhong Univ Sci Technolog Med Sci 34: 363-369, 2014

29. Zhang L, Yang F, Yuan JH, Yuan SX, Zhou WP, Huo XS, Xu D, Bi HS, Wang F and Sun SH: Epigenetic activation of the miR-200 family contributes to H19-mediated metastasis suppression in hepatocellular carcinoma. Carcinogenesis 34: 577-586, 2013.

30. Yang F, Bi J, Xue X, Zheng L, Zhi K, Hua J and Fang G: Up-regulated long non-coding RNA H19 contributes to proliferation of gastric cancer cells. FEBS J 279: 3159-3165, 2012.

31. Zhang EB, Han L, Yin DD, Kong R, De W and Chen J: c-Myc-induced, long, noncoding $\mathrm{H} 19$ affects cell proliferation and predicts a poor prognosis in patients with gastric cancer. Med Oncol 31: 914, 2014.

32. Zhuang M, Gao W, Xu J, Wang P and Shu Y: The long non-coding RNA H19-derived miR-675 modulates human gastric cancer cell proliferation by targeting tumor suppressor RUNX1. Biochem Biophys Res Commun 448: 315-322, 2014.

33. Tsang WP, Ng EK, Ng SS, Jin H, Yu J, Sung JJ and Kwok TT: Oncofetal H19-derived miR-675 regulates tumor suppressor RB in human colorectal cancer. Carcinogenesis 31: 350-358, 2010.

34. Li H, Yu B, Li J, Su L, Yan M, Zhu Z and Liu B: Overexpression of lncRNA H19 enhances carcinogenesis and metastasis of gastric cancer. Oncotarget 5: 2318-2329, 2014.

35. Gupta RA, Shah N, Wang KC, Kim J, Horlings HM, Wong DJ, Tsai MC, Hung T, Argani P, Rinn JL, et al: Long non-coding RNA HOTAIR reprograms chromatin state to promote cancer metastasis. Nature 464: 1071-1076, 2010.

36. Chen FJ, Sun M, Li SQ, Wu QQ, Ji L, Liu ZL, Zhou GZ, Cao G, Jin L, Xie HW, et al: Upregulation of the long non-coding RNA HOTAIR promotes esophageal squamous cell carcinoma metastasis and poor prognosis. Mol Carcinog 52: 908-915, 2013.

37. Hajjari M, Behmanesh M, Sadeghizadeh M and Zeinoddini M: Up-regulation of HOTAIR long non-coding RNA in human gastric adenocarcinoma tissues. Med Oncol 30: 670, 2013

38. Ding C, Cheng S, Yang Z, Lv Z, Xiao H, Du C, Peng C, Xie H, Zhou L, Wu J, et al: Long non-coding RNA HOTAIR promotes cell migration and invasion via down-regulation of RNA binding motif protein 38 in hepatocellular carcinoma cells. Int J Mol Sci 15: 4060-4076, 2014.

39. Ma MZ, Li CX, Zhang Y, Weng MZ, Zhang MD, Qin YY, Gong W and Quan ZW: Long non-coding RNA HOTAIR, a c-Myc activated driver of malignancy, negatively regulates miRNA-130a in gallbladder cancer. Mol Cancer 13: 156, 2014.

40. Kim K, Jutooru I, Chadalapaka G, Johnson G, Frank J, Burghardt R, Kim S and Safe S: HOTAIR is a negative prognostic factor and exhibits pro-oncogenic activity in pancreatic cancer. Oncogene 32: 1616-1625, 2013

41. Lv XB, Lian GY, Wang HR, Song E, Yao H and Wang MH: Long noncoding RNA HOTAIR is a prognostic marker for esophageal squamous cell carcinoma progression and survival. PLoS One 8: e63516, 2013

42. Endo H, Shiroki T, Nakagawa T, Yokoyama M, Tamai K, Yamanami H, Fujiya T, Sato I, Yamaguchi K, Tanaka N, et al: Enhanced expression of long non-coding RNA HOTAIR is associated with the development of gastric cancer. PLoS One 8: e77070, 2013

43. Yang XD, Xu HT, Xu XH, Ru G, Liu W, Zhu JJ, Wu YY, Zhao K, Wu Y, Xing CG, et al: Knockdown of long non-coding RNA HOTAIR inhibits proliferation and invasiveness and improves radiosensitivity in colorectal cancer. Oncol Rep 35: 479-487, 2016.

44. Ge XS, Ma HJ, Zheng XH, Ruan HL, Liao XY, Xue WQ, Chen YB, Zhang Y and Jia WH: HOTAIR, a prognostic factor in esophageal squamous cell carcinoma, inhibits WIF-1 expression and activates Wnt pathway. Cancer Sci 104: 1675-1682, 2013.

45. Song B, Guan Z, Liu F, Sun D, Wang K and Qu H: Long non-coding RNA HOTAIR promotes HLA-G expression via inhibiting miR-152 in gastric cancer cells. Biochem Biophys Res Commun 464: 807-813, 2015.

46. Liu XH, Sun M, Nie FQ, Ge YB, Zhang EB, Yin DD, Kong R, $\mathrm{Xia} \mathrm{R}$, Lu KH, Li JH, et al: Lnc RNA HOTAIR functions as a competing endogenous RNA to regulate HER 2 expression by sponging miR-331-3p in gastric cancer. Mol Cancer 13: 92, 2014. 
47. Liu YW, Sun M, Xia R, Zhang EB, Liu XH, Zhang ZH, $\mathrm{Xu}$ TP, De W, Liu BR and Wang ZX: LincHOTAIR epigenetically silences $m i R 34 a$ by binding to PRC2 to promote the epithelial-to-mesenchymal transition in human gastric cancer. Cell Death Dis 6: e1802, 2015.

48. Zhang H, Diab A, Fan H, Mani SK, Hullinger R, Merle P and Andrisani O: PLK1 and HOTAIR accelerate proteasomal degradation of SUZ12 and ZNF198 during hepatitis B virus-induced liver carcinogenesis. Cancer Res 75: 2363-2374, 2015.

49. Ye P, Wang T, Liu WH, Li XC, Tang LJ and Tian FZ: Enhancing HOTAIR/miR-10b drives normal liver stem cells toward a tendency to malignant transformation through inducing epithelial-to-mesenchymal transition. Rejuvenation Res 18: 332-340, 2015

50. Li H, An J, Wu M, Zheng Q, Gui X, Li T, Pu H and Lu D: LncRNA HOTAIR promotes human liver cancer stem cell malignant growth through downregulation of SETD2. Oncotarget 6: 27847-27864, 2015.

51. Ji P, Diederichs S, Wang W, Böing S, Metzger R, Schneider PM, Tidow N, Brandt B, Buerger H, Bulk E, et al: MALAT-1, a novel noncoding RNA, and thymosin beta4 predict metastasis and survival in early-stage non-small cell lung cancer. Oncogene 22 8031-8041, 2003.

52. Wang X, Li M, Wang Z, Han S, Tang X, Ge Y, Zhou L, Zhou C, Yuan Q and Yang M: Silencing of long noncoding RNA MALAT1 by $\mathrm{miR}-101$ and miR-217 inhibits proliferation, migration, and invasion of esophageal squamous cell carcinoma cells. J Biol Chem 290: 3925-3935, 2015.

53. Okugawa Y, Toiyama Y, Hur K, Toden S, Saigusa S, Tanaka K, Inoue Y, Mohri Y, Kusunoki M, Boland CR, et al: Metastasis-associated long non-coding RNA drives gastric cancer development and promotes peritoneal metastasis. Carcinogenesis 35: 2731-2739, 2014.

54. Xu C, Yang M, Tian J, Wang X and Li Z: MALAT-1: A long non-coding RNA and its important 3 ' end functional motif in colorectal cancer metastasis. Int J Oncol 39: 169-175, 2011.

55. Lai MC, Yang Z, Zhou L, Zhu QQ, Xie HY, Zhang F, Wu LM, Chen LM and Zheng SS: Long non-coding RNA MALAT-1 overexpression predicts tumor recurrence of hepatocellular carcinoma after liver transplantation. Med Oncol 29: 1810-1816, 2012.

56. Wu XS, Wang XA, Wu WG, Hu YP, Li ML, Ding Q, Weng H, Shu YJ, Liu TY, Jiang L, et al: MALAT1 promotes the proliferation and metastasis of gallbladder cancer cells by activating the ERK/MAPK pathway. Cancer Biol Ther 15: 806-814, 2014.

57. Jiao F, Hu H, Han T, Yuan C, Wang L, Jin Z, Guo Z and Wang L: Long noncoding RNA MALAT-1 enhances stem cell-like phenotypes in pancreatic cancer cells. Int J Mol Sci 16 6677-6693, 2015.

58. Ji Q, Zhang L, Liu X, Zhou L, Wang W, Han Z, Sui H, Tang Y, Wang Y, Liu N, et al: Long non-coding RNA MALAT1 promotes tumour growth and metastasis in colorectal cancer through binding to SFPQ and releasing oncogene PTBP2 from SFPQ/PTBP2 complex. Br J Cancer 111: 736-748, 2014.

59. Kan JY, Wu DC, Yu FJ, Wu CY, Ho YW, Chiu YJ, Jian SF, Hung JY, Wang JY and Kuo PL: Chemokine (C-C Motif) Ligand 5 is involved in tumor-associated dendritic cell-mediated colon cancer progression through non-coding RNA MALAT-1. J Cell Physiol 230: 1883-1894, 2015.

60. Yang MH, Hu ZY, Xu C, Xie LY, Wang XY, Chen SY and Li ZG: MALAT1 promotes colorectal cancer cell proliferation/migration/invasion via PRKA kinase anchor protein 9. Biochim Biophys Acta 1852: 166-174, 2015.

61. Zheng HT, Shi DB, Wang YW, Li XX, Xu Y, Tripathi P, Gu WL, Cai GX and Cai SJ: High expression of IncRNA MALAT1 suggests a biomarker of poor prognosis in colorectal cancer. Int J Clin Exp Pathol 7: 3174-3181, 2014.

62. Ji Q, Liu X, Fu X, Zhang L, Sui H, Zhou L, Sun J, Cai J, Qin J, Ren J, et al: Resveratrol inhibits invasion and metastasis of colorectal cancer cells via MALAT1 mediated Wnt/ $\beta$-catenin signal pathway. PLoS One 8: e78700, 2013.

63. Jiao F, Hu H, Yuan C, Wang L, Jiang W, Jin Z, Guo Z and Wang L: Elevated expression level of long noncoding RNA MALAT-1 facilitates cell growth, migration and invasion in pancreatic cancer. Oncol Rep 32: 2485-2492, 2014

64. Hu L, Wu Y, Tan D, Meng H, Wang K, Bai Y and Yang K: Up-regulation of long noncoding RNA MALAT1 contributes to proliferation and metastasis in esophageal squamous cell carcinoma. J Exp Clin Cancer Res 34: 7, 2015.
65. Wang J, Wang H, Zhang Y, Zhen N, Zhang L, Qiao Y, Weng W, Liu X, Ma L, Xiao W, et al: Mutual inhibition between YAP and SRSF1 maintains long non-coding RNA, Malat1-induced tumourigenesis in liver cancer. Cell Signal 26: 1048-1059, 2014.

66. Huang Z, Huang L, Shen S, Li J, Lu H, Mo W, Dang Y, Luo D, Chen $\mathrm{G}$ and Feng Z: Spl cooperates with Sp3 to upregulate MALAT1 expression in human hepatocellular carcinoma. Oncol Rep 34: 2403-2412, 2015.

67. Panzitt K, Tschernatsch MM, Guelly C, Moustafa T, Stradner M, Strohmaier HM, Buck CR, Denk H, Schroeder R, Trauner M, et al: Characterization of HULC, a novel gene with striking up-regulation in hepatocellular carcinoma, as noncoding RNA. Gastroenterology 132: 330-342, 2007.

68. Xie H, Ma H and Zhou D: Plasma HULC as a promising novel biomarker for the detection of hepatocellular carcinoma. BioMed Res Int 2013: 136106, 2013.

69. Li J, Wang X, Tang J, Jiang R, Zhang W, Ji J and Sun B: HULC and Linc00152 Act as Novel Biomarkers in Predicting Diagnosis of Hepatocellular Carcinoma. Cell Physiol Biochem 37: 687-696, 2015.

70. Du Y, Kong G, You X, Zhang S, Zhang T, Gao Y, Ye L and Zhang X: Elevation of highly up-regulated in liver cancer (HULC) by hepatitis B virus X protein promotes hepatoma cell proliferation via down-regulating p18. J Biol Chem 287: 26302-26311, 2012.

71. Zhao Y, Guo Q, Chen J, Hu J, Wang S and Sun Y: Role of long non-coding RNA HULC in cell proliferation, apoptosis and tumor metastasis of gastric cancer: A clinical and in vitro investigation. Oncol Rep 31: 358-364, 2014.

72. Peng W, Gao W and Feng J: Long noncoding RNA HULC is a novel biomarker of poor prognosis in patients with pancreatic cancer. Med Oncol 31: 346, 2014.

73. Wang J, Liu X, Wu H, Ni P, Gu Z, Qiao Y, Chen N, Sun F and Fan Q: CREB up-regulates long non-coding RNA, HULC expression through interaction with microRNA-372 in liver cancer. Nucleic Acids Res 38: 5366-5383, 2010.

74. Cui M, Zheng M, Sun B, Wang Y, Ye L and Zhang X: A long noncoding RNA perturbs the circadian rhythm of hepatoma cells to facilitate hepatocarcinogenesis. Neoplasia 17: 79-88, 2015.

75. Lu Z, Xiao Z1, Liu F, Cui M, Li W, Yang Z, Li J, Ye L and Zhang X: Long non-coding RNA HULC promotes tumor angiogenesis in liver cancer by up-regulating sphingosine kinase 1 (SPHK1). Oncotarget 7: 241-254, 2016.

76. Wan D, Shen S, Fu S, Preston B, Brandon C, He S, Shen C, Wu J, Wang S, Xie W, et al: miR-203 suppresses the proliferation and metastasis of hepatocellular carcinoma by targeting oncogene ADAM9 and oncogenic long non-coding RNA HULC. Anticancer Agents Med Chem 16: 414-423, 2016.

77. Gui X, Li H, Li T, Pu H and Lu D: Long Noncoding RNA CUDR regulates HULC and $\beta$-catenin to govern human liver stem cell malignant differentiation. Mol Ther 23: 1843-1853, 2015.

78. Wylie AA, Murphy SK, Orton TC and Jirtle RL: Novel imprinted DLK1/GTL2 domain on human chromosome 14 contains motifs that mimic those implicated in $I G F 2 / H 19$ regulation. Genome Res 10: 1711-1718, 2000.

79. Peng W, Si S, Zhang Q, Li C, Zhao F, Wang F, Yu J and Ma R: Long non-coding RNA MEG3 functions as a competing endogenous RNA to regulate gastric cancer progression. J Exp Clin Cancer Res 34: 79, 2015

80. Yin DD, Liu ZJ, Zhang E, Kong R, Zhang ZH and Guo RH: Decreased expression of long noncoding RNA MEG3 affects cell proliferation and predicts a poor prognosis in patients with colorectal cancer. Tumour Biol 36: 4851-4859, 2015.

81. Braconi C, Kogure T, Valeri N, Huang N, Nuovo G, Costinean S, Negrini M, Miotto E, Croce CM and Patel T: microRNA-29 can regulate expression of the long non-coding RNA gene $M E G 3$ in hepatocellular cancer. Oncogene 30: 4750-4756, 2011.

82. Modali SD, Parekh VI, Kebebew E and Agarwal SK: Epigenetic regulation of the lncRNA MEG3 and its target c-MET in pancreatic neuroendocrine tumors. Mol Endocrinol 29: 224-237, 2015.

83. Zhou X, Ji G, Ke X, Gu H, Jin W and Zhang G: MiR-141 inhibits gastric cancer proliferation by interacting with long noncoding RNA MEG3 and down-regulating E2F3 expression. Dig Dis Sci 60: 3271-3282, 2015

84. Yan J, Guo X, Xia J, Shan T, Gu C, Liang Z, Zhao W and Jin S: MiR-148a regulates MEG3 in gastric cancer by targeting DNA methyltransferase 1. Med Oncol 31: 879, 2014. 
85.Liu LX, Deng W, Zhou XT, Chen RP, Xiang MQ, Guo YT, $\mathrm{Pu}$ ZJ, Li R, Wang GF and Wu LF: The mechanism of adenosine-mediated activation of IncRNA MEG3 and its antitumor effects in human hepatoma cells. Int J Oncol 48: 421-429, 2016.

86.Zhuo H, Tang J,Lin Z, Jiang R, Zhang X, Ji J, Wang P and Sun B: The aberrant expression of MEG3 regulated by UHRF1 predicts the prognosis of hepatocellular carcinoma. Mol Carcinog 55 209-219, 2016.

87.Zamani M, Sadeghizadeh M, Behmanesh M and Najafi F: Dendrosomal curcumin increases expression of the long non-coding RNA gene $M E G 3$ via up-regulation of epi-miRs in hepatocellular cancer. Phytomedicine 22: 961-967, 2015.

88. Zhou Y, Zhong Y, Wang Y, Zhang X, Batista DL, Gejman R, Ansell PJ, Zhao J, Weng C and Klibanski A: Activation of p53 by MEG3 non-coding RNA. J Biol Chem 282: 24731-24742, 2007.

89. Sun M, Xia R, Jin F, Xu T,Liu Z, De W and Liu X: Downregulated long noncoding RNA MEG3 is associated with poor prognosis and promotes cell proliferation in gastric cancer. Tumour Biol 35: 1065-1073, 2014.

90.Zhu J, Liu S, Ye F, Shen Y, Tie Y, Zhu J, Wei L, Jin Y, Fu H, Wu Y, et al: Long noncoding RNA MEG3 interacts with p53 protein and regulates partial p53 target genes in hepatoma cells. PLoS One 10: e0139790, 2015.

91. Schneider C, King RM and Philipson L: Genes specifically expressed at growth arrest of mammalian cells. Cell 54: 787-793, 1988

92. Yin D, He X, Zhang E, Kong R, De W and Zhang Z: Long noncoding RNA GAS5 affects cell proliferation and predicts a poor prognosis in patients with colorectal cancer. Med Oncol 31: 253,2014 .

93. Sun M, Jin FY, Xia R, Kong R, Li JH, Xu TP, Liu YW, Zhang EB, Liu XH and De W: Decreased expression of long noncoding RNA GAS5 indicates a poor prognosis and promotes cell proliferation in gastric cancer. BMC Cancer 14: 319, 2014.

94. Hu L, Ye H, Huang G, Luo F, Liu Y, Liu Y, Yang X, Shen J, Liu Q and Zhang J: Long noncoding RNA GAS5 suppresses the migration and invasion of hepatocellular carcinoma cells via miR-21. Tumour Biol 37: 2691-2702, 2016.

95. Chang L, Li C, Lan T, Wu L, Yuan Y, Liu Q and Liu Z: Decreased expression of long non-coding RNA GAS5 indicates a poor prognosis and promotes cell proliferation and invasion in hepatocellular carcinoma by regulating vimentin. Mol Med Rep 13: 1541-15450, 2016.

96.Lu X, Fang Y, Wang Z, Xie J, Zhan Q, Deng X, Chen H, Jin J, Peng $\mathrm{C}, \mathrm{Li} \mathrm{H}$, et al: Downregulation of gas 5 increases pancreatic cancer cell proliferation by regulating CDK6. Cell Tissue Res 354: 891-896, 2013.

97.Liu Y, Zhao J, Zhang W, Gan J, Hu C, Huang G and Zhang Y: lncRNA GAS5 enhances G1 cell cycle arrest via binding to YBX1 to regulate $\mathrm{p} 21$ expression in stomach cancer. Sci Rep 5 . 10159,2015

98. Guo X, Deng K, Wang H, Xia J, Shan T, Liang Z, Yao L and Jin S: GAS5 inhibits gastric cancer cell proliferation partly by modulating CDK6. Oncol Res Treat 38: 362-366, 2015.

99. Pasmant E, Laurendeau I, Héron D, Vidaud M, Vidaud D and Bièche I: Characterization of a germ-line deletion, including the entire INK4/ARF locus, in a melanoma-neural system tumor family: Identification of $A N R I L$, an antisense noncoding RNA whose expression coclusters with $A R F$. Cancer Res 67: 3963-3969, 2007.

100. Yap KL, Li S, Muñoz-Cabello AM, Raguz S, Zeng L, Mujtaba S, Gil J, Walsh MJ and Zhou MM: Molecular interplay of the noncoding RNA ANRIL and methylated histone $\mathrm{H} 3$ lysine 27 by polycomb CBX7 in transcriptional silencing of INK $4 \mathrm{a}$. Mol Cell 38: 662-674, 2010

101. Bochenek G, Häsler R, El Mokhtari NE, König IR, Loos BG, Jepsen S, Rosenstiel P, Schreiber S and Schaefer AS: The large non-coding RNA ANRIL, which is associated with atherosclerosis, periodontitis and several forms of cancer, regulates ADIPOR1, VAMP3 and C11ORF10. Hum Mol Genet 22: 45164527, 2013 .

102. Zhang W, Chen Y, Liu P, Chen J, Song L, Tang Y, Wang Y, Liu J, $\mathrm{Hu} F \mathrm{FB}$ and Hui R: Variants on chromosome $9 \mathrm{p} 21.3$ correlated with ANRIL expression contribute to stroke risk and recurrence in a large prospective stroke population. Stroke 43: 14-21, 2012.

103. Chen D, Zhang Z, Mao C, Zhou Y, Yu L, Yin Y, Wu S, Mou X and Zhu Y: ANRIL inhibits p15(INK4b) through the TGF $\beta 1$ signaling pathway in human esophageal squamous cell carcinoma. Cell Immunol 289: 91-96, 2014.
104. Zhang EB, Kong R, Yin DD, You LH, Sun M, Han L, Xu TP, Xia R, Yang JS, De W, et al: Long noncoding RNA ANRIL indicates a poor prognosis of gastric cancer and promotes tumor growth by epigenetically silencing of $\mathrm{miR}-99 \mathrm{a} / \mathrm{miR}-449 \mathrm{a}$. Oncotarget 5: 2276-2292, 2014.

105. Hua L, Wang CY, Yao KH, Chen JT, Zhang JJ and Ma WL: High expression of long non-coding RNA ANRIL is associated with poor prognosis in hepatocellular carcinoma. Int J Clin Exp Pathol 8: 3076-3082, 2015.

106. Naemura M, Tsunoda T, Inoue $Y$, Okamoto H, Shirasawa $S$ and Kotake Y: ANRIL regulates the proliferation of human colorectal cancer cells in both two- and three-dimensional culture. Mol Cell Biochem 412: 141-146, 2016.

107. Huang MD, Chen WM, Qi FZ, Xia R, Sun M, Xu TP, Yin L, Zhang EB, De W and Shu YQ: Long non-coding RNA ANRIL is upregulated in hepatocellular carcinoma and regulates cell apoptosis by epigenetic silencing of KLF2. J Hematol Oncol 8: 50, 2015.

108. Colombo T, Farina L, Macino G and Paci P: PVT1: A rising star among oncogenic long noncoding RNAs. BioMed Res Int 2015: 304208, 2015 .

109. Ding J, Li D, Gong M, Wang J, Huang X, Wu T and Wang C: Expression and clinical significance of the long non-coding RNA PVT1 in human gastric cancer. Onco Targets Ther 7: 1625-1630, 2014.

110. Takahashi Y, Sawada G, Kurashige J, Uchi R, Matsumura T, Ueo H, Takano Y, Eguchi H, Sudo T, Sugimachi K, et al: Amplification of $P V T-1$ is involved in poor prognosis via apoptosis inhibition in colorectal cancers. Br J Cancer 110: 164-171, 2014.

111. Ding C, Yang Z, Lv Z, Du C, Xiao H, Peng C, Cheng S, Xie H, Zhou L, Wu J, et al: Long non-coding RNA PVT1 is associated with tumor progression and predicts recurrence in hepatocellular carcinoma patients. Oncol Lett 9: 955-963, 2015.

112. Huang $\mathrm{C}$, Yu W, Wang Q, Cui H, Wang Y, Zhang L, Han F and Huang T: Increased expression of the lncRNA PVT1 is associated with poor prognosis in pancreatic cancer patients. Minerva Med 106: 143-149, 2015.

113. Kong R, Zhang EB, Yin DD, You LH, Xu TP, Chen WM, Xia R, Wan L, Sun M, Wang ZX, et al: Long noncoding RNA PVTI indicates a poor prognosis of gastric cancer and promotes cell proliferation through epigenetically regulating $\mathrm{p} 15$ and $\mathrm{p} 16 . \mathrm{Mol}$ Cancer 14: 82, 2015.

114. Wang F, Yuan JH, Wang SB, Yang F, Yuan SX, Ye C, Yang N, Zhou WP, Li WL, Li W, et al: Oncofetal long noncoding RNA PVT1 promotes proliferation and stem cell-like property of hepatocellular carcinoma cells by stabilizing NOP2. Hepatology 60: 1278-1290, 2014.

115. Nissan A, Stojadinovic A, Mitrani-Rosenbaum S, Halle D, Grinbaum R, Roistacher M, Bochem A, Dayanc BE, Ritter G, Gomceli I, et al: Colon cancer associated transcript-1: A novel RNA expressed in malignant and pre-malignant human tissues. Int J Cancer 130: 1598-1606, 2012.

116. Alaiyan B, Ilyayev N, Stojadinovic A, Izadjoo M, Roistacher M, Pavlov V, Tzivin V, Halle D, Pan H, Trink B, et al: Differentia expression of colon cancer associated transcript1 (CCAT1) along the colonic adenoma-carcinoma sequence. BMC Cancer 13: 196, 2013.

117. Yang F, Xue X, Bi J, Zheng L, Zhi K, Gu Y and Fang G: Long noncoding RNA CCAT1, which could be activated by c-Myc, promotes the progression of gastric carcinoma. J Cancer Res Clin Oncol 139: 437-445, 2013.

118. Zhu H, Zhou X, Chang H, Li H, Liu F, Ma C and Lu J: CCAT1 promotes hepatocellular carcinoma cell proliferation and invasion. Int J Clin Exp Pathol 8: 5427-5434, 2015.

119. Zhu HQ, Zhou X, Chang H, Li HG, Liu FF, Ma CQ and Lu J: Aberrant expression of CCAT1 regulated by c-Myc predicts the prognosis of hepatocellular carcinoma. Asian Pac J Cancer Prev 16: 5181-5185, 2015

120. He X, Tan X, Wang X, Jin H, Liu L, Ma L, Yu H and Fan Z: C-Myc-activated long noncoding RNA CCAT1 promotes colon cancer cell proliferation and invasion. Tumour Biol 35: 12181-12188, 2014.

121. Deng L, Yang SB, Xu FF and Zhang JH: Long noncoding RNA CCAT1 promotes hepatocellular carcinoma progression by functioning as let-7 sponge. J Exp Clin Cancer Res 34: 18, 2015.

122. Yuan JH, Yang F, Wang F, Ma JZ, Guo YJ, Tao QF, Liu F, Pan W, Wang TT, Zhou CC, et al: A long noncoding RNA activated by TGF- $\beta$ promotes the invasion-metastasis cascade in hepatocellular carcinoma. Cancer Cell 25: 666-681, 2014 
123. Saito T, Kurashige J, Nambara S, Komatsu H, Hirata H, Ueda M, Sakimura S, Uchi R, Takano Y, Shinden Y, et al: A long noncoding RNA activated by transforming growth factor- $\beta$ is an independent prognostic marker of gastric cancer. Ann Surg Oncol 22 (Suppl 3): S915-S922, 2015.

124.Iguchi T, Uchi R, Nambara S, Saito T, Komatsu H, Hirata H, Ueda M, Sakimura S, Takano Y, Kurashige J, et al: A long noncoding RNA, IncRNA-ATB, is involved in the progression and prognosis of colorectal cancer. Anticancer Res 35: 1385-1388, 2015.

125. Yue B, Qiu S, Zhao S, Liu C, Zhang D, Yu F, Peng Z and Yan D: LncRNA-ATB mediated E-cadherin repression promotes the progression of colon cancer and predicts poor prognosis. J Gastroenterol Hepatol 31: 595-603, 2016.

126. Qu S, Yang X, Song W, Sun W, Li X, Wang J, Zhong Y, Shang R, Ruan B, Zhang Z, et al: Downregulation of lncRNA-ATB correlates with clinical progression and unfavorable prognosis in pancreatic cancer. Tumour Biol 37: 3933-3938, 2016.

127. Li W and Kang Y: A new Lnc in metastasis: Long noncoding RNA mediates the prometastatic functions of TGF- $\beta$. Cancer Cell 25: 557-559, 2014.

128. Wang S, Xiang J,Li Z, Lu S, Hu J, Gao X, Yu L, Wang L, Wang J, Wu Y, et al: A plasma microRNA panel for early detection of colorectal cancer. Int J Cancer 136: 152-161, 2015.

129. Paik WH, Song BJ, Kim HW, Kim HR and Hwang JH: MicroRNA-200c as a prognostic biomarker for pancreatic cancer. Korean J Gastroenterol 66: 215-220, 2015

130.Zhou X, Yin C, Dang Y, Ye F and Zhang G: Identification of the long non-coding RNA H19 in plasma as a novel biomarker for diagnosis of gastric cancer. Sci Rep 5: 11516, 2015.

131. Quackenbush JF, Cassidy PB, Pfeffer LM, Boucher KM, Hawkes JE, Pfeffer SR, Kopelovich L and Leachman SA: Isolation of circulating microRNAs from microvesicles found in human plasma. Methods Mol Biol 1102: 641-653, 2014.

132. Arita T, Ichikawa D, Konishi H, Komatsu S, Shiozaki A, Shoda K, Kawaguchi T, Hirajima S, Nagata H, Kubota T, et al: Circulating long non-coding RNAs in plasma of patients with gastric cancer. Anticancer Res 33: 3185-3193, 2013.

133. Orozco AF and Lewis DE: Flow cytometric analysis of circulating microparticles in plasma. Cytometry A 77: 502-514, 2010

134. Record M, Subra C, Silvente-Poirot S and Poirot M: Exosomes as intercellular signalosomes and pharmacological effectors. Biochem Pharmacol 81: 1171-1182, 2011.

135.Li Q, Shao Y, Zhang X, Zheng T, Miao M, Qin L, Wang B, Ye G, Xiao B and Guo J: Plasma long noncoding RNA protected by exosomes as a potential stable biomarker for gastric cancer. Tumour Biol 36: 2007-2012, 2015.

136. Paoletti X, Oba K, Burzykowski T, Michiels S, Ohashi Y, Pignon JP, Rougier P, Sakamoto J, Sargent D, Sasako M, et al; GASTRIC (Global Advanced/Adjuvant Stomach Tumor Research International Collaboration) Group: Benefit of adjuvant chemotherapy for resectable gastric cancer: A metaanalysis. JAMA 303: 1729-1737, 2010.

137. Svoboda M, Slyskova J, Schneiderova M, Makovicky P, Bielik L, Levy M, Lipska L, Hemmelova B, Kala Z, Protivankova M, et al: HOTAIR long non-coding RNA is a negative prognostic factor not only in primary tumors, but also in the blood of colorectal cancer patients. Carcinogenesis 35: 1510-1515, 2014.

138. Yang Z, Zhou L, Wu LM, Lai MC, Xie HY, Zhang F and Zheng SS: Overexpression of long non-coding RNA HOTAIR predicts tumor recurrence in hepatocellular carcinoma patients following liver transplantation. Ann Surg Oncol 18: 1243-1250, 2011.

139.Li X, Wu Z, Mei Q, Li X, Guo M, Fu X and Han W: Long non-coding RNA HOTAIR, a driver of malignancy, predict negative prognosis and exhibits oncogenic activity in oesophageal squamous cell carcinoma. Br J Cancer 109: 2266-2278, 2013.
140. Tu ZQ, Li RJ, Mei JZ and Li XH: Down-regulation of long non-coding RNA GAS5 is associated with the prognosis of hepatocellular carcinoma. Int J Clin Exp Pathol 7: 4303-4309, 2014.

141.Zhang XW, Bu P, Liu L, Zhang XZ and Li J: Overexpression of long non-coding RNA PVT1 in gastric cancer cells promotes the development of multidrug resistance. Biochem Biophys Res Commun 462: 227-232, 2015.

142. Wang Y, Zhang D, Wu K, Zhao Q, Nie Y and Fan D: Long noncoding RNA $M R U L$ promotes $A B C B 1$ expression in multidrug-resistant gastric cancer cell sublines. Mol Cell Biol 34: 3182-3193, 2014.

143. Li Z, Zhao X, Zhou Y, Liu Y, Zhou Q, Ye H, Wang Y, Zeng J, Song Y, Gao W, et al: The long non-coding RNA HOTTIP promotes progression and gemcitabine resistance by regulating HOXA13 in pancreatic cancer. J Transl Med 13: 84, 2015.

144. Sorin V, Ohana P, Mizrahi A, Matouk I, Birman T, Hochberg A and Czerniak A: Regional therapy with DTA-H19 vector suppresses growth of colon adenocarcinoma metastases in the rat liver. Int J Oncol 39: 1407-1412, 2011.

145. Sorin V, Ohana P, Gallula J, Birman T, Matouk I, Hubert A, Gilon M, Hochberg A and Czerniak A: H19-promoter-targeted therapy combined with gemcitabine in the treatment of pancreatic cancer. ISRN Oncol 2012: 351750, 2012.

146. Hanna N, Ohana P, Konikoff FM, Leichtmann G, Hubert A, Appelbaum L, Kopelman Y, Czerniak A and Hochberg A: Phase $1 / 2 \mathrm{a}$, dose-escalation, safety, pharmacokinetic and preliminary efficacy study of intratumoral administration of BC-819 in patients with unresectable pancreatic cancer. Cancer Gene Ther 19: 374-381, 2012

147. Burnett JC and Rossi JJ: RNA-based therapeutics: Current progress and future prospects. Chem Biol 19: 60-71, 2012.

148. Zhang ZZ, Shen ZY, Shen YY, Zhao EH, Wang M, Wang CJ, $\mathrm{Cao} \mathrm{H}$ and $\mathrm{Xu} \mathrm{J}$ : HOTAIR long noncoding RNA promotes gastric cancer metastasis through suppression of poly $\mathrm{r}(\mathrm{C})$ binding brotein (PCBP) 1. Mol Cancer Ther 14: 1162-1170, 2015.

149. Konishi H, Ichikawa D, Yamamoto Y, Arita T, Shoda K, Hiramoto H, Hamada J, Itoh H, Fujita Y, Komatsu S, et al: Plasma level of metastasis-associated lung adenocarcinoma transcript 1 is associated with liver damage and predicts development of hepatocellular carcinoma. Cancer Sci 107: 149-154, 2016.

150.Pang EJ, Yang R, Fu XB and Liu YF: Overexpression of long non-coding RNA MALAT1 is correlated with clinical progression and unfavorable prognosis in pancreatic cancer. Tumour Biol 36: 2403-2407, 2015.

151. Mizrahi I, Mazeh H, Grinbaum R, Beglaibter N, Wilschanski M, Pavlov V, Adileh M, Stojadinovic A, Avital I, Gure AO, et al: Colon cancer sssociated transcript-1 (CCAT1) expression in adenocarcinoma of the stomach. J Cancer 6: 105-110, 2015.

152. Cao X, Zhao R, Chen Q, Zhao Y, Zhang B, Zhang Y, Yu J, Han G, Cao W, Li J, et al: MALAT1 might be a predictive marker of poor prognosis in patients who underwent radical resection of middle thoracic esophageal squamous cell carcinoma. Cancer Biomark 15: 717-723, 2015.

153. Wang J, Su L, Chen X, Li P, Cai Q, Yu B, Liu B, Wu W and Zhu Z: MALAT1 promotes cell proliferation in gastric cancer by recruiting SF2/ASF. Biomed Pharmacother 68: 557-564, 2014.

154. You L, Chang D, Du HZ and Zhao YP: Genome-wide screen identifies PVT1 as a regulator of gemcitabine sensitivity in human pancreatic cancer cells. Biochem Biophys Res Commun 407: 1-6, 2011. 